\title{
Application of innovative technologies in agriculture of Uzbekistan
}

\author{
Gulnora Narinbaeva ${ }^{1 *}$, Bakhtiyor Menglikulov ${ }^{1}$, Zokhid Siddikov $^{1}$, Komiljon Bustonov $^{1}$, \\ and Sanjar Davlatov ${ }^{1}$ \\ ${ }^{1}$ Tashkent State Agrarian University, 100140, Tashkent province, Uzbekistan
}

\begin{abstract}
The issues of the development of innovative processes in agriculture in Uzbekistan on the example of the Tashkent province were revealed in this paper. The assimilation and further widespread dissemination of innovations are becoming key factors in the growth of production and employment in agriculture. It is here that the most significant reserves for improving product quality, saving labor and material costs, increasing labor productivity, improving the organization of production and increasing its efficiency are hidden. All this, ultimately, predetermines the competitiveness of enterprises and their products in the domestic and world markets, improvement of the socio-economic situation in the country's agricultural sector. In this regard, the relevance of this study was determined.
\end{abstract}

\section{Introduction}

Agriculture is one of the most socially significant sectors of the national economy. Important priority areas for the development of agriculture are: saturation of the domestic market with food products, achieving self-sufficiency in their production and ensuring food security [1]. The effective implementation of these tasks makes it possible to solve such pressing social issues as employment of the population, increasing its well-being, and improvement of cities and villages [2].

The effective development of agriculture in modern conditions requires the constant emergence and implementation of new technologies, the improvement of economic relations between producers and consumers of scientific products, the formation of such a policy for the development of the agro-industrial complex, which should be based on the basic provisions of the transition of the country's economy to an innovative path of development [3].

Innovation is always associated with the demand for innovation in a particular situation and the presence of investment potential [4]. The structure of the economy is changing under the influence of innovation. Indeed, due to the increase in the efficiency of the use of resources, some of them are released and redistributed to other areas of activity. For example, the share of people employed in agriculture is declining, while in the service

\footnotetext{
* Corresponding author: gulnora.narinbaeva@yandex.com
} 
sector it is increasing. In addition, innovations are the direct cause of the emergence of new industries, industries and the gradual withering away of existing ones [5].

Innovation is also changing the economic organization of society. New social institutions and economic organizations (for example, venture capital firms) appear, the content of the interrelationships between them is transformed. There are shifts in the ownership structure [6]. Management technologies are improving: vertical impacts are increasingly supplemented and replaced by horizontal ones. The content of state regulation of the economy is also undergoing changes [7].

Modernization and intensive development of agriculture, widespread introduction of intensive methods into agricultural production, primarily modern water and resource-saving agricultural technologies, the use of high-performance agricultural machinery; Expansion of research work on the creation and introduction into production of new breeding varieties of agricultural crops resistant to diseases and pests, adapted to local soil-climatic and environmental conditions, and animal breeds with high productivity [8-10].

The problems of the theory of innovations are becoming more and more relevant; arouse increased interest among many scientists, as evidenced by the constantly increasing volume of publications, both in foreign and domestic science [11-14]. The problems of the development of innovative processes in agriculture are the most serious today and are relevant for further study.

\section{Materials and methods}

The theoretical basis of the study was the works of domestic and foreign scientistseconomists on the problems of the theory of innovation, innovation, the development of innovative processes in rural areas, as well as legislative and other regulations governing innovation [15].

To solve the tasks set in the work, general scientific and special methods of cognition were used as tools: comparative, economic and statistical grouping of data, tabular methods of economic analysis and synthesis, a graphical method, a generalization method, a method of expert assessments [11-13].

The theoretical significance of the results obtained, scientific conclusions and practical recommendations can be used as a theoretical basis for further development of the problems of the development of innovative processes in agriculture, as well as to draw up a set of applied recommendations for the implementation of innovations in farms necessary to improve the efficiency of agricultural production on the basis of accelerated introduction of innovative developments into production, creation of competitive products at all stages of production [16].

The practical significance lies in the development of basic directions and specific recommendations, the use of which will improve the development of innovative processes, both in the public administration system and at the level of individual farms.

\section{Results and discussion}

\subsection{Analysis of the current state of agriculture in Tashkent province}

The most important direction of sustainable and effective development of agriculture is its transfer to intensive methods of management through the introduction of modern agricultural technologies and equipping with high-performance agricultural machinery.

Let us consider the main indicators of the activity of farms in the Tashkent province, Uzbekistan (Table 1). 
Table 1. Production of crop products in the Tashkent province, in ' 000 tons.

\begin{tabular}{|c|c|c|c|c|c|c|}
\hline Indicators & $\mathbf{2 0 1 4}$ & $\mathbf{2 0 1 5}$ & $\mathbf{2 0 1 6}$ & $\mathbf{2 0 1 7}$ & $\mathbf{2 0 1 8}$ & $\begin{array}{c}\text { Values of 2018 } \\
\text { relative to 2014, \% }\end{array}$ \\
\hline Cereals & 707.9 & 742.6 & 771.8 & 753.7 & 698.2 & 98 \\
\hline Raw cotton & 231.3 & 230.4 & 237.1 & 237.2 & 201.5 & 87 \\
\hline Potatoes & 319.7 & 336.7 & 361.4 & 398.3 & 437.6 & 136 \\
\hline Vegetables & 1572.0 & 1716.9 & 1841.7 & 2036.9 & 2244.3 & 142 \\
\hline Melons & 130.2 & 132.5 & 144.8 & 150.1 & 162.3 & 124 \\
\hline Fruits and berries & 166.4 & 173.1 & 188.5 & 204.7 & 223.0 & 134 \\
\hline Grapes & 139.4 & 140.9 & 155.9 & 167.9 & 174.1 & 124 \\
\hline
\end{tabular}

In 2018, the farms of the Tashkent province grew 698,200 tons of grain (98\% against the indicator of 2014), 201,500 tons of raw cotton (87\%), 2,244,300 tons of vegetables $(142 \%), 437,600$ tons of potatoes $(136 \%), 162,300$ tons of melons $(124 \%), 223,000$ tons of fruits and berries (134\%) and 74,100 tons of grapes (124\%) (Table 2).

Table 2. Production of crop and livestock products by farms in the Tashkent province, in ' 000 tons.

\begin{tabular}{|c|c|c|c|c|c|c|}
\hline Indicators & $\mathbf{2 0 1 4}$ & $\mathbf{2 0 1 5}$ & $\mathbf{2 0 1 6}$ & $\mathbf{2 0 1 7}$ & $\mathbf{2 0 1 8}$ & $\begin{array}{c}\text { Values of 2018 } \\
\text { relative to } \\
\mathbf{2 0 1 4 ,} \%\end{array}$ \\
\hline Cereals & 648.0 & 679.1 & 702.4 & 682.8 & 624.4 & 96 \\
\hline Raw cotton & 240.2 & 229.0 & 236.5 & 236.7 & 201.0 & 83 \\
\hline Potatoes & 119.2 & 125.8 & 132.2 & 142.8 & 152.8 & 128 \\
\hline Vegetables & 644.9 & 721.3 & 772.6 & 799.9 & 879.9 & 121 \\
\hline Melons & 96.5 & 99.2 & 105.3 & 107.8 & 116.8 & 120 \\
\hline $\begin{array}{c}\text { Fruits and } \\
\text { berries }\end{array}$ & 87.2 & 93.5 & 102.2 & 114.4 & 121.5 & 139 \\
\hline Grapes & 78.9 & 83.7 & 93.9 & 90.4 & 103.0 & 131 \\
\hline Meat & 8.0 & 8.5 & 9.7 & 9.9 & 10.6 & 132 \\
\hline Milk & 33.6 & 34.1 & 35.8 & 38.0 & 40.4 & 120 \\
\hline $\begin{array}{c}\text { Eggs, } \\
\text { million unit }\end{array}$ & 81.9 & 79.6 & 63.4 & 63.9 & 57.9 & 70 \\
\hline Wool & 429 & 501 & 671 & 674 & 685 & 159 \\
\hline
\end{tabular}

The indicators for the production of livestock products also tended to grow, as the production of meat in 2018 increased by $32 \%$ compared to 2014 , milk - $20 \%$, and wool $59 \%$.

In Uzbekistan, much attention is paid to the creation and development of diversified farms, which are not limited only to the cultivation of crops or animal husbandry, but are also engaged in the in-depth processing of agricultural products and the provision of services to the rural population.

According to the Program for the Development of Multidisciplinary Farms in 2016, projects were implemented in the Republic of Uzbekistan to create additional farms in production and service areas. So in the Tashkent province, as of January 1, 2017, 2,422 additional multi-profile farms were created [11].

Land resources are one of the main national treasures of our country. Complete, reliable, objective information about land is essential for land management in general and for the development of sustainable agriculture in particular [12].

Rational use of the land fund involves the creation and improvement of a management system that allows the most efficient use of land resources.

Fig. 1 shows the structure of the land area used by land users engaged in agricultural production in the Tashkent province. The total land area is 777.6 hectares, of which the area 
of agricultural land is $56.2 \%$, household land use, garden and vegetable garden plots $11.9 \%$, and others (forest plantations) $-31.9 \%$.

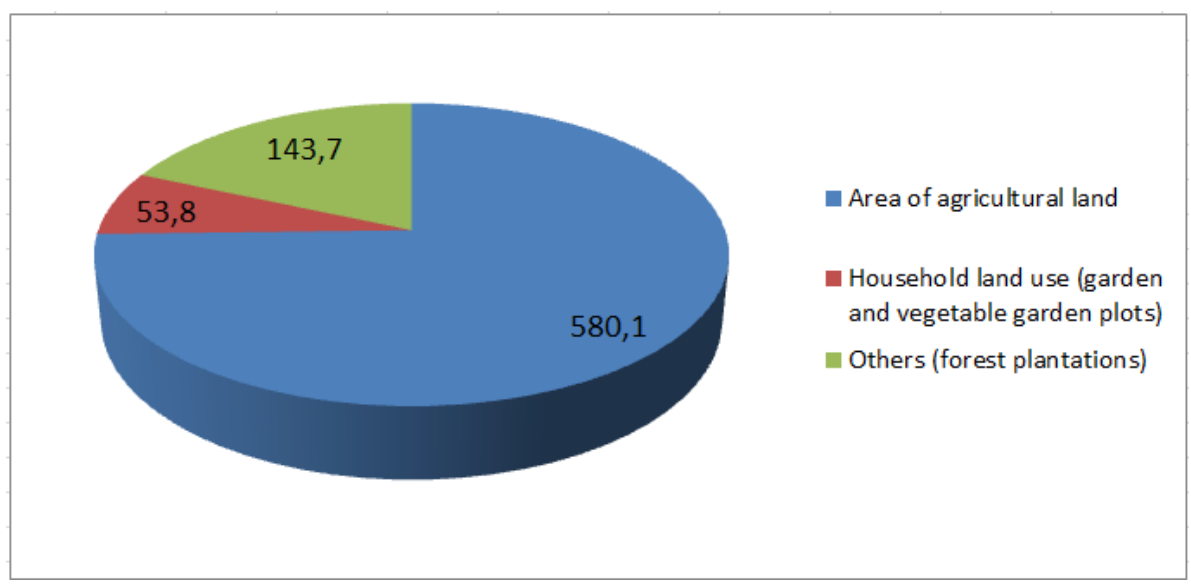

Fig. 1. Structure of the land area used by land users engaged in agricultural production in the Tashkent province, in hectares (2018).

Table 3 presents data on the dynamics of changes in the area of agricultural land. Based on the data in Table 3, we can conclude that the total area of agricultural land in the Tashkent province, including its structure, has changed over the past four years. At the same time, the total land area is equal to the area of agricultural land and it is used quite rationally, since arable land in the total land area is $98 \%$.

Table 3. Agricultural lands of the Tashkent province, ha.

\begin{tabular}{|c|c|c|c|c|c|c|c|}
\hline Indicators & $\mathbf{2 0 1 3}$ & $\mathbf{2 0 1 4}$ & $\mathbf{2 0 1 5}$ & $\mathbf{2 0 1 6}$ & $\mathbf{2 0 1 7}$ & $\mathbf{2 0 1 8}$ & $\begin{array}{c}\text { Values of } \\
\mathbf{2 0 1 8} \\
\text { relative to } \\
\mathbf{2 0 1 3}, \boldsymbol{\%}\end{array}$ \\
\hline Farmland & 575.0 & 575.0 & 577.0 & 576.7 & 580.3 & 580.1 & 101 \\
\hline $\begin{array}{c}\text { Including: arable } \\
\text { land }\end{array}$ & 335.5 & 335.5 & 333.7 & 332.4 & 329.7 & 329.1 & 98 \\
\hline Irrigated land & 336.2 & 336.2 & 337.4 & 337.3 & 339.1 & 338.9 & 101 \\
\hline $\begin{array}{c}\text { Sown area of all } \\
\text { agricultural crops }\end{array}$ & 360.1 & 360.1 & 355.6 & 354.6 & 353.3 & 353.5 & 98 \\
\hline
\end{tabular}

In order to analyze the dynamics and structure of indicators of the use of land resources in the region, it is necessary to determine the composition and structure of the sown areas of agricultural crops in the region for several years (Table 4).

From 2015 to 2018, the area underwent a 1\% decrease in acreage: from 355,600 hectares to 353,500 hectares. The largest share in the structure of crops is consistently occupied by potatoes, cotton and grain crops $-44 \%$ and $26 \%$, respectively, on average over 4 years.

The economic efficiency of land use in agriculture is characterized by a system of natural and cost indicators. The main ones are the following: yield of agricultural crops, $\mathrm{kg} / \mathrm{ha}$; the cost of gross production, gross and net income, profit per 1 hectare, UZS; recoupment of costs in land resources, UZS per $100 \mathrm{UZS}$ of material costs; differential income, UZS/ha; and, profitability of production, $\%$. 
Table 4. Composition and structure of sown areas of agricultural crops in the Tashkent province.

\begin{tabular}{|c|c|c|c|c|c|c|c|c|c|}
\hline \multirow[b]{2}{*}{ Indicators } & \multicolumn{2}{|c|}{2015} & \multicolumn{2}{|c|}{2016} & \multicolumn{2}{|c|}{2017} & \multicolumn{2}{|c|}{2018} & \multirow{2}{*}{$\begin{array}{c}\text { Values of } \\
2018 \\
\text { relative to } \\
2015, \% \\
\end{array}$} \\
\hline & $\begin{array}{c}\text { '000 } \\
\text { ha }\end{array}$ & $\%$ & $\begin{array}{c}\text { '000 } \\
\text { ha }\end{array}$ & $\%$ & $\begin{array}{c}\text { '000 } \\
\text { ha }\end{array}$ & $\%$ & $\begin{array}{c}\text { '000 } \\
\text { ha }\end{array}$ & $\%$ & \\
\hline $\begin{array}{c}\text { Total sowing } \\
\text { area }\end{array}$ & 355.6 & 100 & 354.6 & 100 & 353.3 & 100 & 353.5 & 100 & 99 \\
\hline including: & 159.0 & 44 & 159.3 & 45 & 159.7 & 45 & 155.5 & 44 & 98 \\
\hline Cereals & 98.2 & 27 & 95.6 & 27 & 94.4 & 27 & 89.2 & 26 & 91 \\
\hline Raw cotton & 8.6 & 2 & 8.8 & 3 & 9.0 & 3 & 10.1 & 3 & 117 \\
\hline Potatoes & 34.2 & 9 & 33.7 & 9 & 33.3 & 9 & 36.8 & 10 & 108 \\
\hline Vegetables & 4.2 & 1 & 4.3 & 1 & 4.5 & 1 & 4.9 & 1 & 117 \\
\hline Melons & 42.7 & 12 & 44.8 & 13 & 44.5 & 13 & 48.8 & 14 & 114 \\
\hline Other crops & 8.7 & 5 & 8.1 & 2 & 7.9 & 2 & 8.2 & 2 & 94 \\
\hline
\end{tabular}

An analysis of the yield and gross agricultural output in the Tashkent province is presented in Table 5. From the data in the table, it can be seen that the indicators of yield and gross production in 2018 compared to 2015 increased.

Table 5. Dynamics of gross harvests and yields of the main field crops in the Tashkent province.

\begin{tabular}{|c|c|c|c|c|c|c|c|c|c|c|}
\hline \multirow[b]{2}{*}{ 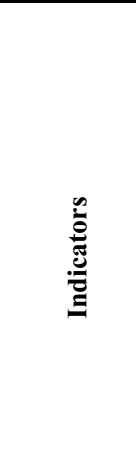 } & \multicolumn{2}{|c|}{2015} & \multicolumn{2}{|c|}{2016} & \multicolumn{2}{|c|}{2017} & \multicolumn{2}{|c|}{2018} & \multirow[b]{2}{*}{ 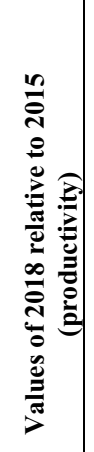 } & \multirow[b]{2}{*}{ 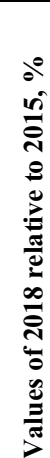 } \\
\hline & 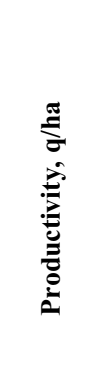 & 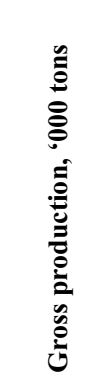 & 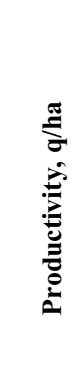 & 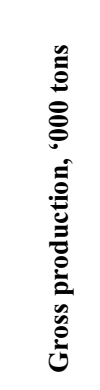 & 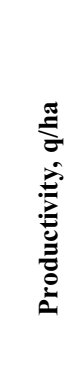 & 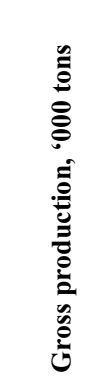 & 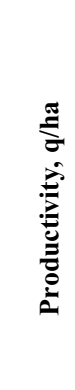 & 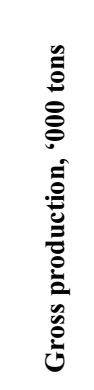 & & \\
\hline Cereals & 44.8 & 742.6 & 46.0 & 771.8 & 44.3 & 753.7 & 42.0 & 698.2 & 94 & 94 \\
\hline $\begin{array}{c}\text { Raw } \\
\text { cotton }\end{array}$ & 23.4 & 230.4 & 24.2 & 237.1 & 26.7 & 237.2 & 24.5 & 201.5 & 105 & 87 \\
\hline Potatoes & 232.4 & 336.7 & 236.6 & 361.4 & 239.6 & 398.3 & 233.3 & 437.6 & 69 & 130 \\
\hline Vegetables & 271.7 & $1,716.9$ & 274.2 & $1,841.7$ & 283.3 & $2,036.9$ & 281.4 & $2,244.3$ & 104 & 131 \\
\hline Melons & 213.7 & 132.5 & 214.7 & 144.8 & 218.7 & 150.1 & 221.0 & 162.3 & 103 & 122 \\
\hline
\end{tabular}

Table 6 shows the dynamics and economic indicators of the efficiency of the use of land resources in the Tashkent province. Analyzing the data in Table 6, one can see that in 2018, 1,854 million UZS of gross agricultural production were produced per 100 hectares of arable land, which is 80 percent higher than in 2015, of which 1,128 million UZS are crop production and 678 million UZS are livestock products. In 2018, 1,053 million UZS of gross output were produced per 100 hectares of agricultural land, which exceeded this figure for 2015 by 77 percent, of which crop production - 641 million UZS, and livestock 385 million UZS.

The main directions of development of the agrarian sector of the Tashkent province are [11-15]:

- increasing the efficiency of the use of land and water resources of the region, aimed at increasing the yield and productivity of agricultural products, by improving the condition of land and water systems; 
- strengthening the material and technical base of rural producers based on the intensification of investment activities, the expansion of leasing operations and the creation of alternative MTPs;

- improvement of agricultural regulation mechanisms aimed at ensuring sustainable development of the industry, increasing its competitiveness, reducing barriers to entry of agricultural producers into the markets;

- creation of favorable conditions for agricultural producers.

Table 6. Economic indicators of the use of land resources in the Tashkent province.

\begin{tabular}{|c|c|c|c|c|c|c|}
\hline Indicators & $\mathbf{2 0 1 4}$ & $\mathbf{2 0 1 5}$ & $\mathbf{2 0 1 6}$ & $\mathbf{2 0 1 7}$ & $\mathbf{2 0 1 8}$ & $\begin{array}{c}\text { Values of } \\
\text { 2018 relative } \\
\text { to 2014, \% }\end{array}$ \\
\hline $\begin{array}{c}\text { Agricultural products, billion } \\
\text { UZS }\end{array}$ & 3411.9 & 4178.7 & 4813.0 & 5371.5 & 6115.5 & 179 \\
\hline $\begin{array}{c}\text { Gross production per 100 } \\
\text { hectares of arable land, million } \\
\text { UZS }\end{array}$ & 1016 & 1245 & 1442 & 1592 & 1854 & 180 \\
\hline $\begin{array}{c}\text { Per 100 hectares of agricultural } \\
\text { land, million UZS }\end{array}$ & 593 & 726 & 834 & 931 & 1053 & 177 \\
\hline $\begin{array}{c}\text { Gross crop production produced, } \\
\text { billion UZS }\end{array}$ & 2124.6 & 2567.7 & 3029.3 & 3356.6 & 3720.9 & 175 \\
\hline $\begin{array}{c}\text { Per 100 hectares of arable land, } \\
\text { million UZS }\end{array}$ & 633 & 765 & 834 & 907 & 1128 & 178 \\
\hline $\begin{array}{c}\text { Per 100 hectares of agricultural } \\
\text { land, million UZS }\end{array}$ & 369 & 446 & 525 & 582 & 641 & 173 \\
\hline $\begin{array}{c}\text { Gross livestock production, } \\
\text { billion UZS }\end{array}$ & 1287.3 & 1533.0 & 1683.0 & 1867.6 & 2236.2 & 173 \\
\hline $\begin{array}{c}\text { Per 100 hectares of arable land, } \\
\text { million UZS }\end{array}$ & 383 & 456 & 504 & 560 & 678 & 177 \\
\hline $\begin{array}{c}\text { Per 100 hectares of agricultural } \\
\text { land, million UZS }\end{array}$ & 223 & 266 & 291 & 323 & 385 & 172 \\
\hline $\begin{array}{c}\text { The share of arable land in the } \\
\text { composition of agricultural land, } \\
\text { \% }\end{array}$ & 58 & 58 & 57 & 58 & 56 & - \\
\hline
\end{tabular}

The development of agriculture is ensured by solving the problems of developing market infrastructure, access to material and financial resources, improving the regulatory framework in the activities of agricultural producers, aimed at providing greater economic freedom to commodity producers.

Thus, the analysis carried out allows us to conclude that the agriculture of the Tashkent province has favorable prospects for its further development. The started stable growth of gross output in agriculture creates objective preconditions for the re-creation of stable production systems on a fundamentally new market basis, through deepening economic reforms.

\subsection{Effectiveness of the implementation of an innovative project in agriculture in the Tashkent province}

A feature of the modern period of development of all branches and spheres of agroindustrial production is the need to accelerate scientific and technological progress based on innovative processes that allow for a continuous renewal of production based on the development of the achievements of science, technology and advanced experience. World experience shows that innovation processes, as a rule, are not only encouraged, but also regulated by the state through the formation of an appropriate policy and systematic organization of innovation. 
This section presents data from the analysis of the effectiveness of the use of innovations aimed at more efficient use of water, land and material resources in the Tashkent province.

Water resources play a key role in agriculture in Uzbekistan. Lack of water resources can negatively affect not only agricultural production, but also the development of the economy as a whole [8]. In addition to climatic reasons (droughts), the reason for the shortage of water resources is the low efficiency of irrigation water use [12]. Therefore, today there is a need for a transition to new effective and affordable water-saving technologies. The use of the method of laser leveling of agricultural lands is one of such technologies [15].

Laser leveling of land, measuring soil salinity and nitrogen content in crops, as well as an innovative integrated approach to transform degraded arable land into forest plantations - all these innovations not only improve the environment, but are also economically viable [14].

Laser leveling involves not only leveling the land, but also more efficient use and conservation of water resources. Currently, the technology of laser land leveling has been tested and adapted for the conditions of Uzbekistan. It is easy to implement, which will improve the efficiency of water use, water conservation and water distribution. Additionally, this technology contributes to high yields and sustainable agricultural production. Laser leveling technology is ready to scale up with adequate funding and consulting services for farmers. The following analysis describes the costs and benefits of introducing this innovative technology using the example of the Tashkent province [9-11].

In the conditions of irrigated agriculture, the flat surface of the field is one of the main factors ensuring the efficient use of water resources, obtaining a high yield and economic stability.

Laser leveling means a method of leveling the ground using a laser installation using special equipment, when the difference in the unevenness of the field surface is only $+/-3$ $\mathrm{cm}$ or less, while with the traditional method, the unevenness of the field can fluctuate significantly higher. Laser leveling technology is widely used in the construction of dwellings, highways, and can also be used for leveling agricultural land, conducting irrigation canals, and drainage and collector systems.

Based on the results obtained in the course of research on experimental fields of farms in the Tashkent province, the following advantages of this technology in comparison with the traditional method were revealed [11-15]:

- saving of irrigation water by $20-25 \%$;

- reduction of soil salinity;

- uniform soil moisture;

- reduction of irrigation time, labor and energy consumption;

- uniform emergence of seedlings;

- increase in grain yield of wheat and raw cotton by 4-7 q/ha;

- additional profit by increasing crop yields.

Analysis of the effectiveness of this technology shows that the use of this innovation is a self-sustaining and cost-effective measure (Table 7). When using laser leveling, additional profit in the cultivation of wheat is $85,000 \mathrm{UZS}$, and of cotton $-79,000 \mathrm{UZS}$ per hectare. This effect is achieved, on the one hand, by increasing yields (wheat by 4 quintals $(\mathrm{q}) / \mathrm{ha}$ and cotton by $2.5 \mathrm{q} / \mathrm{ha}$ ) and, on the other hand, by reducing the cost of some agricultural activities, such as furrowing, praying and labor for watering. At the same time, significant savings are also achieved in the total water consumption per 1 ha of both wheat $\left(1714 \mathrm{~m}^{3}\right)$ and cotton $\left(2000 \mathrm{~m}^{3}\right)$ per year. 
Table 7. Indicators of economic efficiency of the use of laser land leveling technology (per 1 ha).

\begin{tabular}{|c|c|c|c|c|}
\hline Indicators & Conventional & Laser land & \multicolumn{2}{|c|}{ Changes* } \\
\cline { 4 - 5 } & approach & leveling & $\#$ & \%* \\
\hline \multicolumn{5}{|c|}{ Wheat } \\
\hline Total costs, '000 UZS & 1090.3 & 1131.3 & 41 & 3.7 \\
\hline Water consumption, m ${ }^{3}$ & 5725 & 4011 & -1714 & $(30)$ \\
\hline Yield, q/ha & 40.0 & 44.0 & 4 & 10 \\
\hline Income, '000 UZS & 1,260 & 1,386 & 126 & 10 \\
\hline Profit, '000 UZS & 169.7 & 254.7 & 85 & 50.1 \\
\hline Profitability, \% & 15.5 & 22.5 & 7 & \\
\hline \multicolumn{5}{|c|}{ Cotton } \\
\hline Total costs, '000 UZS & 1371.3 & 1443.1 & 71.8 & 5.2 \\
\hline Water consumption, m ${ }^{3}$ & 10000 & 8000 & -2000 & $(20)$ \\
\hline Yield, q/ha & 25 & 27.5 & 2.5 & 10 \\
\hline Income, '000 UZS & 1508.5 & 1659.3 & 150.8 & 10 \\
\hline Profit, '000 UZS & 137.2 & 216.2 & 79 & 57.6 \\
\hline Profitability, \% & 10 & 15 & 5 & - \\
\hline *Decrease in percentage is indicated in brackets \\
\hline
\end{tabular}

The total cost of laser equipment purchased directly in Tashkent (from the representative office of Leica Geosystems) is 1,863,400 UZS, to which are added the costs of customs clearance of equipment $(0.2 \%)$. The payback of these rather significant investments can be achieved through additional profits for a period from 1 to 3 years, depending on the source of borrowed funds and the size of the land plot (Table 8). For example, to cover the cost of the purchased laser equipment for 3 years, a farmer will need: for wheat from 38 to 56 hectares and for cotton from 39 to 58 hectares.

Table 8. Payback of laser equipment.

\begin{tabular}{|c|c|c|c|c|c|}
\hline Form of financing & 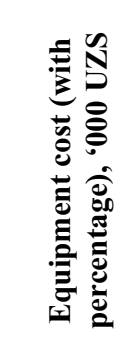 & 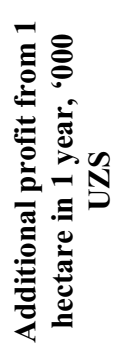 & 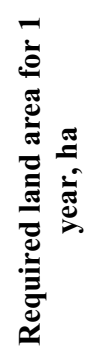 & 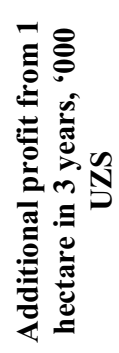 & 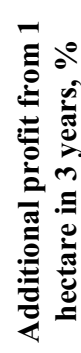 \\
\hline \multicolumn{6}{|c|}{ Wheat } \\
\hline Own funds & 18633.9 & 85.0 & 219 & 490.3 & 38 \\
\hline Leasing, $14 \%$ & 26460.1 & 85.0 & 250 & 490.3 & 54 \\
\hline $\begin{array}{c}\text { Credit from commercial } \\
\text { banks, } 16 \%\end{array}$ & 27578.2 & 85.0 & 254 & 490.3 & 56 \\
\hline \multicolumn{6}{|c|}{ Cotton } \\
\hline Own funds & 18633.9 & 79.0 & 236 & 472.3 & 39 \\
\hline Leasing, $14 \%$ & 26460.1 & 79.0 & 335 & 472.3 & 56 \\
\hline $\begin{array}{c}\text { Credit from commercial } \\
\text { banks, } 16 \%\end{array}$ & 27578.2 & 79.0 & 349 & 472.3 & 58 \\
\hline
\end{tabular}

To calculate the effect of using laser leveling at the regional level (Table 9), we proceeded from the following prerequisites:

- productivity of one laser planner 3-4 hectares per day or 300 hectares for 1 year (3 months of intensive field work when the land is not occupied by crops); 
- the average annual area of cotton is 105,000 hectares, wheat - 48,500 hectares, in the amount of 153,500 hectares;

- for a phased (within 3 years) leveling of cotton and wheat fields, 171 sets of laser equipment are required $(153,500 \mathrm{ha} / 300 \mathrm{ha}=512 \mathrm{pcs} / 3$ years $=171 \mathrm{pcs})$.

Table 9. Effect of the use of laser land leveling technology on the example of the Tashkent province.

\begin{tabular}{|c|c|c|c|}
\hline & First year & Second year & Third year \\
\hline Investment in laser equipment, '000 UZS & 3178115 & - & - \\
\hline Investment in laser equipment, USD & 1961557 & - & - \\
\hline Wheat & & & \\
\hline Planned land area, ha & 16167 & 32333 & 48500 \\
\hline Additional profit per hectare, '000 UZS & 85 & 203 & 203 \\
\hline Additional profit in total, '000 UZS & 1374768 & 6552486 & 9828729 \\
\hline Cotton & & & \\
\hline Planned land area, ha & 35000 & 70000 & 105000 \\
\hline Additional profit per hectare, '000 UZS & 79 & 197 & 197 \\
\hline Additional profit in total, '000 UZS & 2766306 & 13765801 & 20648702 \\
\hline $\begin{array}{c}\text { Total additional profit for cotton and } \\
\text { wheat, '000 UZS }\end{array}$ & 4141074 & 20318287 & 30477430 \\
\hline $\begin{array}{c}\text { Net additional profit after covering the } \\
\text { investment, '000 UZS }\end{array}$ & 962958 & 20318287 & 30477430 \\
\hline
\end{tabular}

An increase in yields due to laser land planning will make it possible to obtain additional profit both at the farm level and at the level of the entire region, which in the first year will amount to more than 4.14 billion UZS, excluding investments. In the third year, net additional profit at the regional level may already amount to more than 30.5 billion UZS (Table 9). In addition to economic efficiency, the use of laser land planning will save a large amount of water. The required volume of irrigation water at the regional level for traditional cultivation of wheat is 277.7 million $\mathrm{m}^{3}\left(48,500\right.$ ha $\left.\mathrm{x} 5,725 \mathrm{~m}^{3}\right)$, and cotton 1,050 million $\mathrm{m}^{3}\left(105,000\right.$ ha $\left.\mathrm{x} 10,000 \mathrm{~m}^{3}\right)$. The required volume of irrigation water at the regional level when cultivating wheat using laser land planning technology will be only 194.5 million $\mathrm{m}^{3}$ of water, and for cotton -840 million $\mathrm{m}^{3}$. Thus, the total saving of irrigation water at the province level can amount to 293.2 million $\mathrm{m}^{3}$ of water, or $7.3 \%$ of the total annual agricultural water consumption of the Tashkent province.

Irrigation water in Uzbekistan is commonly used for flood and furrow irrigation. Therefore, the efficiency of use depends on the uniformity of the field surface. Laser leveling achieves this uniform microtopography and is beneficial for all crops.

\section{Conclusions}

Thus, according to the results obtained in the course of research on experimental fields of farms in the Tashkent province, the following advantages of laser land leveling technology were revealed in comparison with the traditional method: saving irrigation water by 20 $25 \%$; reduction of soil salinity; uniform soil moisture; reduction in watering time, labor and energy costs; uniform emergence of seedlings; increasing the yield of wheat grain and raw cotton by $4-7 \mathrm{q} / \mathrm{ha}$; additional profit by increasing crop yields.

The main barriers to the widespread introduction of laser planning technology and other innovative developments are the lack of working capital, the lack of necessary knowledge and contacts from farmers to purchase the necessary equipment. As a solution to the problem, it is proposed to make a centralized purchase of the necessary equipment through authorized bodies. This should be supported by the selection and provision of an optimal source of financing with the participation of, for example, commercial banks. 


\section{References}

1. U. Mukhtorov, E3S Web of Conferences, 244, 03013 (2021)

2. A.A. Abduvosikov, M. Mirzaev, Kh. Shodmonkhujaev, J. Karimova, The modern ecological state of the natural environment and scientific and practical aspects of rational nature management, 3470-3474 (2016)

3. P.A. Andreev, Innovative processes in agriculture, 184 (2012)

4. O.V. Astafeva, Regional Economics: Theory and Practice, 5, 109-118 (2016)

5. S.D. Ilenkova, Innovative management, 327 (2012)

6. M.Yu. Kirsanov, Formation of a national innovation system for the development of the regional economy, 168 (2015)

7. M.Kh. Kamilova, K.A. Khodjaev, Russia: Trends and Development Prospects, 1, 692 (2013)

8. Sh.M. Ruziev, F.Kh. Khamroev, R. Umarov, Sh. Kodirov, Introduction of resourcesaving technologies for growing wheat in farms, 28 (2012)

9. I. Sandu, Agroindustrial complex: economics, management, 11, 73-80 (2005)

10. N.S. Dekhkanova, International Journal for Innovative Research in Multidisciplinary Field, 5(11), 52-57 (2019)

11. N.S. Dekhkanova, J. Rozikov, O. Tonkix, F. Yakubov, International Journal Of Research Culture Society, 4(1), 128-135 (2020)

12. F.R. Galimova, International Journal Of Research Culture Society, 4(1), 121-127 (2020)

13. G.K. Narinbaeva, F.R. Islamov, S.A. Davlatov, G.B. Ergashev, Journal of Science and Healthcare Exploration (JSHE), 1(6), 6 (2019)

14. I.B. Rustamova, F.R. Galimova, Actual science: International scientific journal, Volgograd: SIC “Absolute”, 4(9), 12-16 (2018)

15. B.Yu. Menglikulov, R. Tashmatov, N. Boltaev, A. Axmetov, N. Dexkanova, International Journal of Recent Technology and Engineering (IJRTE), 8(4), 7 (2020)

16. S. Islamov, N. Namozov, M. Saidova, D. Kodirova, E3S Web of Conferences, 244, $03028(2021)$ 